\title{
THE CLADONIA PYXIDATA-FIMBRIATA COMPLEX IN THE NETHERLANDS, WITH DESCRIPTION OF A NEW VARIETY
}

\author{
H. J. M. SIPMAN \\ Instituut voor Systematische Plantkunde, Utrecht
}

\section{SUMMARY}

A morphological, chemical, and ecological analysis was performed on a large number of collections of Cladonia pyxidata and related taxa from the Netherlands. The following species are recognized: Cladonia fimbriata, $\mathrm{Cl}$. conistea, $\mathrm{Cl}$. conista, $\mathrm{Cl}$. pyxidata, $\mathrm{Cl}$. chlorophaea, $\mathrm{Cl}$. cryptochlorophaea, $\mathrm{Cl}$. merochlorophaea and $\mathrm{Cl}$. grayi. A strain with novochlorophaeic acid is described as a new variety: $\mathrm{Cl}$. merochlorophaea Asah. var. novochlorophaea (colour reactions: $\mathrm{P} \rightarrow$ orange-red or often negative; $\mathrm{K} \rightarrow$ negative; $\mathrm{C} \rightarrow$ negative or yellow; $\mathrm{KC} \rightarrow$ negative).

In morphological and ecological respect a close relationship has been found between 1. Cladonia conistea and $\mathrm{Cl}$. conista, and 2. Cladonia cryptochlorophaea and $\mathrm{Cl}$. merochlorophaea.

For comparison also some material from other European countries has been studied.

\section{INTRODUCTION}

The group of lichens with which this paper is concerned, conveniently called the Cladonia pyxidata-fimbriata complex, comprises Cladonia pyxidata(L.) Hoffm., Cl. fimbriata (L.) Fr., and a number of closely related species which in this century have been separated from them, mainly on the basis of their chemistry. These include, i.a., Cladonia conista (Ach.) Robb., Cl. grayi Merr. ex Sandst., Cl. cryptochlorophaea Asah. and Cl. merochlorophaea Asah. (CulBerson \& KRISTINSSON 1969).

The occurrence in Europe of these species was studied mainly by AsAHINA (1940, 1941), AHTI (1966), and LeUCKERT et al. (1972), the second author working especially with Finnish, the third with Central European material. No Dutch material was included in these studies. Reports of species belonging to this complex from the Netherlands by MAAS GeEsTeranus (1954) and Hennipman (1969) comprise Cladonia fimbriata, Cl. pyxidata var. chlorophaea Flk., and $\mathrm{Cl}$. pyxidata var. grayi Merr., the last-named variety being distinguished by its negative P-reaction after SANDSTEDE (1938).

Since the taxonomic value of these new species, often considered as chemical strains, was questioned by some authors (DAHL 1950), a more extensive study of the differences between them was necessary. For this an examination of the morphology, chemistry, and ecology of the taxa is required. To eliminate a good deal of the variation caused by geographical isolation or large climatical differences, a study of larger sets of material from limited areas seemed to be 
indicated. Comparison of the results from several such studies will give a better understanding of the taxa in their whole range. Such studies have already been undertaken in Finland (AHTI 1966) and the U.S.A. (KRISTINSSON 1971). The large amounts of material collected in the Netherlands offered another, excellent opportunity; the results of the study of this material are described in the following.

\section{MATERIAL AND METHODS; NOTES ON THE CHARACTERS EMPLOYED}

The specimens examined, over 700 collections, mainly from the Netherlands, are preserved in the institutional herbaria of Leiden (L), Utrecht (U), and Wijster (WAG-W), and in the private herbaria of Groot \& van Soest and the author's. The number of collections of each species is given in parentheses after the name of the country concerned.

For the chemical analysis, microcrystal-tests with acetone-extraction were used (Thомson 1968). Besides, colour reactions were checked on filter-paper impregnated with part of the extract. For the $\mathrm{C}$ reaction a bleach for domestic use was applied. This occasionally produces a colour reaction different from that of the usual calcium-hypochlorite solution, in particular the $\mathrm{C} \rightarrow$ yellow reaction in Cladonia merochlorophaea var. novochlorophaea (see below). After some experience, observation of the dried acetone extract together with the colour reactions in most cases proved to be reliable for identification.

All measurements have been taken from dry material. The dimensions of the soredia and granulae generally were determined on the surface of well-developed cups with the aid of a microscope with ocular micrometer. The smallest measurements given are from young stages of soredia or granulae, the larger ones from fully developed stages. The soredia and granulae were distinguished from scales by their rounded shape and the absence of lobes.

The nomenclature follows AHTI (1966).

An insight into the ecology of the species was obtained by study of the accompanying mosses and lichens and of remnants of the substrate, as present in the collections, in connection with data on habitat and vegetation from the labels.

It is remarkable that the dimensions of the soredia and granulae found by the author are smaller than those given by some other authors. In Cladonia cryptochlorophaea, for example, the diameter of the soredia was found to be $20-80 \mu \mathrm{m}$, contrasting with $30-130 \mu \mathrm{m}$ in KRISTINSSON (1971). It is true that the measurements of Kristinsson were based on wet, thus swollen material, whereas the author worked with dried material. However, it is the author's impression that this does not satisfactorily explain the differences. Climatical differences probably are responsible.

As to the apothecia in the Cladonia pyxidata-fimbriata complex, two types could be distinguished.

The simple type occurs in most species, like $\mathrm{Cl}$. fimbriata, $\mathrm{Cl}$. conistea, Cl. pyxidata, and Cl.chlorophaea. Here the apothecia are larger, with an 
unbranched stalk. In early stages of apothecial development a disc-shaped hymenium is present which may be shortly stalked. In larger stages (with the hymenium over $0.5 \mathrm{~mm}$ in diameter) a hole appears in the middle of the hymenium, giving the apothecium a ring-like shape. Now a well developed stalk mostly is present ( $f \mathrm{~g} . b, d^{2}$ ). In apothecia up to $5 \mathrm{~mm}$ in diameter the hymenial ring may be curled or dissolved, in extreme cases giving the appearance of several rings, but all at the same level on one stalk ( $f g . d^{1}$ ). Rarely on very broad stalks more apothecia are present from the onset.

The other, compound type is present in Cladonia cryptochlorophaea, $\mathrm{Cl}$. merochlorophaea, and $\mathrm{Cl}$.grayi. In these species the stalks are often branched, bearing several small, ring-shaped apothecia rarely over $1 \mathrm{~mm}$ in diameter. The branches of the stalks are mostly very short, yielding a glomerule-like groupment, sometimes over $4 \mathrm{~mm}$ in diameter, of small, connected apothecia ( $\mathrm{fig} . \mathrm{g}$ ). The pycnidia, too, may have branched stalks.

AHTI (1966) already noted this unusual arrangement of the apothecia. He referred to Cladonia merochlorophaea as having "somewhat flattened proliferations bearing large, dark brown groups of apothecia".

The colour of the apothecia does not seem to have much taxonomic value. In all species of the complex it generally is dark brown, but sometimes a remarkable light colour occurs, as, for instance, in Cladonia cryptochlorophaea.

\section{THE SPECIES}

1. Cladonia fimbriata (L.) Fr.

SANDSTEDe (1931) 430, pl. 30, fig. 4,5 (not var. conista); Aнti (1966); Thомson (1968) 109, no. 64; HenNipMAN (1969) 34, pl. 16, fig. a-e.

Dried acetone extract: crystals not over $10 \mu \mathrm{m}$, inconspicuous. No larger crystals produced with a GAW test.

Colour reactions: $\mathrm{P} \rightarrow$ orange-red; $\mathrm{K} \rightarrow$ negative (weakly orange, after a few minutes brownish); $\mathrm{C} \rightarrow$ negative; $\mathrm{KC} \rightarrow$ negative.

Morphology: farinose soredia of c. $10-40 \mu \mathrm{m}$ in diam. present all over the cups, on the stalks and sometimes on the thallus-lobes; thallus-leaves up to 3 $\mathrm{mm}$ long, c. $0.15 \mathrm{~mm}$ thick, with $0.3-1 \mathrm{~mm}$ wide lobes; podetia with long stalks and shallow cups, rarely proliferating; apothecia c. 1-3 $\mathrm{mm}$ wide, simple (HENNIPMAN 1969, pl. 16, figs. a-e).

Specimens from tree trunks bearing poorly developed cups may be difficult to distinguish from comparable forms of Cladonia chlorophaea (see below).

Distribution and ecology: occuring all over the country, on poor, weakly acid sandy or loamy soil, mainly on steep banks, often together with Ceratodon purpureus and Cladonia conistea, or epiphytic on several kinds of trees.

Material examined: Netherlands (161); Germany (1); Norway (2); Great Britain (2); France (2); Spain (1); Switzerland (1); Austria (2); Czechoslovakia (4). 
2. Cladonia conistea (Del.) Asah.

Asahina (1941, as forma); Leuckert \& Poelt (1970).

Dried acetone extract: with rod-shaped, colourless, $20-30 \mu \mathrm{m}$ long crystals accumulating just behind the outer margin of the extract. With a GAW test the same result was obtained. The presence of atranorin was confirmed several times by a GAoT test.

Colour reactions: $\mathrm{P} \rightarrow$ orange-red; $\mathrm{K} \rightarrow$ yellow, often difficult to distinguish from the reaction $\mathrm{K} \rightarrow$ negative (weakly orange, after a few minutes brownish); $\mathrm{C} \rightarrow$ negative; $\mathrm{KC} \rightarrow$ negative.

Morphology: farinose soredia of $10-40 \mu \mathrm{m}$ in diam. present all over the cups and sometimes on the thallus-leaves, which are $3-5(-7) \mathrm{mm}$ long and c. $0.15 \mathrm{~mm}$ thick, with c. $1 \mathrm{~mm}$ wide lobes; podetia with short stalks and deep cups, rarely proliferating; apothecia rarely present, ca. $1 \mathrm{~mm}$ wide, simple (figs. $j, k$ ).

In exposed sites, for instance on the Wadden Islands, the species is conspicuous by its strongly developed thallus leaves curled up and exposing their white lower side when dry; its podetia are small and whitish. Inland forms generally have a smaller thallus and larger podetia with longer stalks. Proliferating podetia with cups on three levels were seen in a collection from Bretagne (de Smidt s.n. 6.VII.1963, U).

Distribution and ecology; occurring all over the Netherlands, on weakly acid, sandy or loamy soil, frequently in weakly calcareous sand-dunes and often associated with Ceratodon purpureus and Cladonia fimbriata, rarely epiphytic.

A find of the species on a dam near the harbour of Terschelling suggests that it may be salt tolerant.

Material examined: Netherlands (73); Great Britain (2); France (5); Portugal (1).

3. Cladonia conista (Ach.) Robb.

AsAHINA (1941); Ahti (1966); Thomson (1968) 109, no. 63.

Very close to Cladonia conistea from which it differs in chemistry only; instead of atranorin Cladonia conista contains "substance H", which may be seen in the dried acetone extract as very long (often over $100 \mu \mathrm{m}$ ) colourless needles arranged in a criss-cross pattern. The same result is obtained with the GAW test. The $\mathrm{K}$ reaction is negative.

According to LeUCKERT \& POELT (1970) all reports of atranorin in Cladonia conista are due to confusion with $\mathrm{Cl}$. conistea.

Apothecia were not seen in the material studied.

Distribution and ecology: the few records from the Netherlands suggest similarity to Cladonia conistea.

Material examined: Netherlands (8); Czechoslovakia (1).

4. Cladonia pyxidata (L.) Hoffm.

SANDSTEDe (1931) 403, pl. 29, fig. 6, 7, 9; Ahti (1966).

Dried acetone extract: crystals not over $10 \mu \mathrm{m}$, inconspicuous. The same result is obtained with the GAW test. 
Colour reactions: $\mathrm{P} \rightarrow$ orange-red; $\mathrm{K} \rightarrow$ negative (weakly orange, after a few minutes brownish); $\mathrm{C} \rightarrow$ negative; $\mathrm{KC} \rightarrow$ negative.

Morphology: granulae c. 50-300 $\mu \mathrm{m}$ in diam., present on the membrane and sometimes on the outer surface of the cups, often developing into areolae; thallus-leaves 3-10 $\mathrm{mm}$ long and up to $0.5 \mathrm{~mm}$ thick, with 1-2 mm wide lobes, often forming a rosette [var. pocillum (Ach.) Flot.]; podetia with short stalks and deep cups, rarely proliferating; apothecia c. 1-4 mm wide, simple (figs. $a-c)$.

The specimens from the Dutch coastal sand-dunes often have smaller granulae, c. $30-150 \mu \mathrm{m}$ in diam., and narrower thallus-lobes. Rosettes are often formed. A part of this material is difficult to distinguish from Cladonia chlorophaea (see below).

Distribution and ecology: mainly in the coastal dunes on calcareous sand, often overgrowing mosses like Tortula spp., Camptothecium lutescens, and Hypnum cupressiforme var. lacunosum. Also found in the chalk grasslands of South Limburg and in inland sanddunes rich in lichens. Rarely epiphytic.

Material examined: Netherlands (70); Germany (4); Sweden (2); Norway (6); Great Britain (6); Ireland (1); France (5); Spain (2); Portugal (3); Switzerland (5); Greece (1); Malta (3).

\section{Cladonia chlorophaea (Flk. ex Sommerf.) Spreng. em. Asah.}

Asahina (1940); Ahti (1966); Thomson (1968) 105, no. 59.

Dried acetone extract: crystals not over $10 \mu \mathrm{m}$, inconspicuous. The same result is obtained with the GAW test.

Colour reactions: $\mathrm{P} \rightarrow$ orange-red; $\mathrm{K} \rightarrow$ negative (weakly orange, after a few minutes brownish); $\mathrm{C} \rightarrow$ negative; $\mathrm{KC} \rightarrow$ negative.

Morphology: granular soredia, c. 20-80 $\mu \mathrm{m}$ in diam., present all over the cups; thallus-leaves up to $1.5 \mathrm{~mm}$ long and c. $0.15 \mathrm{~mm}$ thick, with $0.2-0.5 \mathrm{~mm}$ wide, inconspicuous lobes; podetia with short or rather long stalks and deep, sometimes shallow cups which often proliferate; apothecia c. 1-3 mm wide, simple (figs. $d, e$ ).

Some specimens are difficult to distinguish from Cladonia fimbriata and $\mathrm{Cl}$. pyxidata (see above).

Distribution and ecology: common all over the Netherlands, on weakly acid, sandy or loamy soil, often together with Ceratodon purpureus but also often with Pohlia nutans and Polytrichum piliferum, sometimes epiphytic.

In the Netherlands the species seems to prefer less acid substrates than the next species. The same is observed in Finland (АнтI 1966).

Material examined: Netherlands (133); Germany (1); Great Britain (1); Ireland (1); France (2); Czechoslovakia (1).

\section{Cladonia cryptochlorophaea Asah:}

Asahina (1940); Ahti (1966); Thomson (1968) 108, no. 62.

Dried acetone extract: on the edge a more or less complete gummy ring is developed with black stains which at high magnification appear granular and 
typically have a striped pattern. With GAW trichites are formed with a straight base and a strongly curled upper part. These are characteristic of cryptochlorophaeic acid (AsAHINA 1940; ThOMSON 1968). From one podetium much thicker trichites without straight base were obtained. The production of these aberrant crystals may have been caused by some chemical reaction during the preparation.

Colour reactions: $\mathrm{P} \rightarrow$ orange-red; $\mathrm{K} \rightarrow$ orange, after a few minutes claret; $\mathrm{C} \rightarrow$ rosy for one second; $\mathrm{KC} \rightarrow$ strongly rosy for one second.

Because of the positive P-reaction all material belongs to f. cryptochlorophaea Asah.

Morphology: similar to Cladonia chlorophaea, but cups not shallow; apothecia c. $0.5-1 \mathrm{~mm}$ wide, compound (figs. $f, g$ ).

Distribution and ecology: common all over the Netherlands on acid, \pm organic substrates: on humous soil in heathlands and dry forests, and on bark of Quercus and Betula. Often growing together with Dicranum scoparium, Pohlia nutans, and Cladonia spp.

Most collections are a mixture of Cladonia cryptochlorophaea and Cl. merochlorophaea. These species could not be separated morphologically. The only reliable difference between them is in their chemistry. Their distribution differs somewhat: in the Netherlands Cladonia cryptochlorophaea seems to be somewhat more common in the southern part of the country. $\mathrm{Cl}$. merochlorophaea in the North. In other countries such differences are more distinct (KRISTINSSON 1971).

Material examined: Netherlands (107); Belgium (6); Germany (2); Norway (1); Great Britain (2).

\section{Cladonia merochlorophaea Asah.}

Asahina (1940); Ahti (1966); Thomson (1968) 108, no. 61; Culberson \& KRISTINSSON (1969).

A. var. merochlorophaea

Dried acetone extract: on the edge a more or less complete gummy ring is developed with local accumulations of rod-shaped, colourless crystals of $c$. $40 \mu \mathrm{m}$ in length. Black, granular, never striped stains are sometimes present. In low concentrations only fine, curved crystals are formed. With GAW oblong, flat crystals with oblique ends are obtained: merochlorophaeic acid (ASAHINA 1940; THOMSON 1968).

They may be solitary or aggregated in stellate clusters. In some collections, for instance Buse s.n., 1850, Wolfhees (L), also needle-shaped crystals were observed, which may become aggregated into long, branched patterns. In one collection, Saaltink s.n., 1.IX.1963 (U), this was the only type of crystals obtained. The needle-shaped crystals may represent 4-0-methyl-cryptochlorophaeic acid which according to CULBERSON \& KRISTINSSON (1969) is also present in Cladonia merochlorophaea. It is possible that these crystals have often been overlooked, as they are difficult to distinguish from crystals of merochlorophaeic acid in lateral view. 
Colour reactions: contrary to the observations of most authors, no differences in colour reactions between Cladonia merochlorophaea and Cl. cryptochlorophaea were seen, except for the $\mathrm{P}$ reaction, which in Cl.merochlorophaea is sometimes weak or negative: $f$. inactiva Asah. The P-positive specimens are called $f$. merochlorophaea.

Morphology: as in Cladonia cryptochlorophaea (fig. h).

AHTi (1966) described two types. All material seen seems to belong to his type I.

Distribution and ecology: as in Cladonia cryptochlorophaea. P-negative specimens were found only in the north-eastern part of the Netherlands and in N.W. Germany.

Material examined: Netherlands $(116 \mathrm{P}+, 6 \mathrm{P}-)$; Belgium $(1 \mathrm{P}+)$; Germany (6 P+, $2 \mathrm{P}-)$; Denmark (1 P+); Great Britain (3 P+); Ireland (1 P+); France (2 P+); Austria (1 P+); Czechoslovakia (1 P+).

B. var. novochlorophaea Sipman var. nov.

Diagnosis: A varietate typica differt acidum novochlorophaeicum continente, solutionibus $\mathrm{KOH}$ et $\mathrm{CaClO}$ non rubescente. - Differs from the typical variety by the possession of novochlorophaeic acid, and by the absence of red colour reactions with $\mathrm{KOH}$ and $\mathrm{CaClO}$ solutions.

Typus: Netherlands, island of Terschelling, N.W. edge of the Boschplaat, coastal sand-dunes, in open grassy vegetation on acid, sandy soil, 8.X.1971, Sipman 4895 (U).

This new variety differs from the type of Cladonia merochlorophaea only in its chemistry. The presence of a novochlorophaeic acid-containing strain has been observed by DAHL (1950), AHTI (1966), and LeUCKERT et al. (1972). The difference in the colour reaction has apparently been overlooked.

Dried acetone extract: on the edge a more or less complete gummy ring, better developed than in the last two taxa, is formed. Locally accumulations of short, prismatic, colourless crystals are present. Sometimes oblong, brownish crystals arranged in radiate groups are also present.

With GAW thick, prismatic, colourless crystals are obtained which originate very slowly from oil droplets; often it is better to make the observations after an overnight's wait. They may appear as small, rhombic double prisms, often crossing in pairs. Sometimes they form groups of rather large, single prisms.

Various other types of colourless crystals may be present: oblong, thick ones, oblong and flat ones, and large or small needle-shaped ones. These aberrant crystals may dominate the prismatic ones.

The prismatic crystals fit the description of novochlorophaeic acid as given by DAHL (1950) and Thomson (1968). Culberson \& Kristinsson (1969) made chromatograms of the novochlorophaeic acid strain and found a mixture of sekikaik (dominant) and homosekikaik acid.

AHTI (1966) reported the occurrence of merochlorophaeic acid in the novochlorophaeic acid strain. In the course of the present study crystals were found resembling those of merochlorophaeic acid, but absence of the characteristic colour reactions indicated that they belong to some other substance. 
Colour reactions: $\mathrm{P} \rightarrow$ orange-red, often weak or negative; $\mathrm{K} \rightarrow$ negative (sometimes weakly orange, after a few minutes brownish); $\mathbf{C} \rightarrow$ yellow (see remark in Material and methods); $\mathrm{KC} \rightarrow$ negative.

Morphology: as in Cladonia cryptochlorophaea (fig. i).

Distribution and ecology: in general as in the two previous taxa, with which it often grows intermingled. P-negative specimens are most common in the northern part of the country and are absent from the South.

Material examined: Netherlands (35 P+, $30 \mathrm{P}-$ ); Belgium (2 P+); Germany (1 P+, $2 \mathrm{P}-)$; Denmark (1 P-); Great Britain (1 P-); Ireland (1 P+).

\section{Cladonia grayi Merr. ex Sandst.}

Aнti (1966); Thomson (1968) 107, no. 60.

Dried acetone extract: on the edge $30-50 \mu \mathrm{m}$ long needle-shaped colourless crystals are accumulated. With GAW colourless, separate or clustered needles of $50-100 \mu \mathrm{m}$ are obtained.

Colour reactions: $\mathrm{P} \rightarrow$ orange-red; $\mathrm{K} \rightarrow$ at first negative, after a few minutes claret; $\mathrm{C} \rightarrow$ negative; $\mathrm{KC} \rightarrow$ negative, for one second with a weak, dark stain.

According to Thomson (1968) the $\mathrm{K}$ reaction should be negative. The P-positive material is called $\mathrm{f}$. aberrans Asah.

Morphology: In the scanty material from the Netherlands no clear morphological differences with the two foregoing species could be found. According to AHTI (1966) the apothecial groups and the soredia are smaller than those of Cladonia merochlorophaea. KRISTINSSON (1971) found a considerable overlap in the size of the soredia of $\mathrm{Cl}$. grayi and Cl. cryptochlorophaea.

A more distant relationship between Cladonia grayi and $\mathrm{Cl}$. cryptochlorophaea with $\mathrm{Cl}$. merochlorophaea was suggested by SHIBATA \& CHIANG (1965) on account of the chemical structure of their lichen acids.

Distribution and ecology: an overall resemblance with the two foregoing species was found, but they were not found growing together.

The distribution in the Netherlands is restricted to a small area in the East ("subcentreuroop district"), probably an outpost of a more continental range.

Material examined: Netherlands (4); Belgium (1); Austria (1); Poland (1).

\section{KEY TO THE SPECIES}

1. - With pulverulent soredia (c. $40 \mu \mathrm{m}$ in diam.); thallus lobes $0,3-1 \mathrm{~mm}$ wide; P-positive. . . . . . . . . . . . . . . . . 2

- With granular soredia (c. $80 \mu \mathrm{m}$ in diam.); thallus lobes $0,2-0,5 \mathrm{~mm}$ wide; P-positive or P-negative. . . . . . . . . . . . . . . . 4

- With corticate granulae (c. 150-300 $\mu \mathrm{m}$ in diam.); thallus lobes c. 1-2 mm wide; P-positive. . . . . . . . . . . 4. Cl. pyxidata

2. - Stalks soredious, long: at least twice as long as the shallow cups.

1. Cl. fimbriata

- Stalks corticate, short: at most twice as long as the deep cups. . . . 3 
3. - With atranorin; $\mathrm{K} \rightarrow$ yellow (sometimes weakly). . . . 2. Cl. conistea - With substance $\mathrm{H}$; K-negative. . . . . . . . . . 3. Cl. conista

4. - Apothecia rather large, each on a separate stalk; P-positive, K-negative; only with fumarprotocetraric acid. . . . . . . . . 5. Cl. chlorophaea

- Apothecia rather small, mostly grouped in a glomerule on a common stalk; P-positive or -negative, $\mathrm{K} \rightarrow$ reddish or negative . . . . . . 5

5. - With cryptochlorophaeic acid; P-positive, $\mathrm{K} \rightarrow$ claret.

6. Cl. cryptochlorophaea

- With merochlorophaeic acid; P-positive or P-negative, $\mathrm{K} \rightarrow$ claret.

7A. Cl. merochlorophaea var. merochlorophaea

- With novochlorophaeic acid; P-positive or -negative, K-negative.

7B. var. novochlorophaea

- With grayaninic acid; P-positive, K-negative. . . . . . . 8. Cl. grayi

\section{DISCUSSION}

In the Netherlands eight species are distinguished in the Cladonia pyxidatafimbriata complex, one of them with two varieties.

On a morphological basis they can be arranged in 5 groups: 1. Cladonia fimbriata; 2. Cladonia conistea and Cl. conista; 3. Cladonia pyxidata; 4. Cladonia chlorophaea; 5. Cladonia cryptochlorophaea, Cl. merochlorophaea var. merochlorophaea and var. novochlorophaea, and $\mathrm{Cl}$. grayi. Transitions seem to occur between Cladonia pyxidata and $\mathrm{Cl}$. chlorophaea. Separating Cladonia fimbriata from $\mathrm{Cl}$. chlorophaea may be difficult when the specimens are poorly developed.

In chemical respect Cladonia fimbriata, Cl. pyxidata and $\mathrm{Cl}$. chlorophaea agree because only fumarprotocetraric acid is demonstrable. Besides this, Cladonia conistea and $\mathrm{Cl}$. conista possess atranorin and a substance " $\mathrm{H}$ ", respectively. Cladonia cryptochlorophaea, $\mathrm{Cl}$. merochlorophaea and $\mathrm{Cl}$.grayi agree by the occurrence of a gummy residue after acetone extraction; furthermore variable amounts of fumarprotocetraric acid and several other substances may occur.

Ecologically Cladonia fimbriata, $\mathrm{Cl}$. conistea, $\mathrm{Cl}$. conista and $\mathrm{Cl}$. chlorophaea agree in occurring on poor, rather acid substrates. Cladonia pyxidata has in the Netherlands a preference for calcareous substrates. Cladonia cryptochlorophaea, $\mathrm{Cl}$. merochlorophaea and $\mathrm{Cl}$. grayi usually grow on strongly acid substrate, often on thick humus in forests and heathland.

The distribution patterns are not likely to show relevant differences in the relatively small area studied. Most groups seem to be equally distributed over the whole country, wherever suitable habitats are present. Cladonia merochlorophaea var. novochlorophaea is more common in the North, its P-negative variant occurs there exclusively; the P-negative variant of var. merochlorophaea only occurs in the North-East; $\mathrm{Cl}$. cryptochlorophaea is more common in the 
South, and $\mathrm{Cl}$. grayi has only been found in a small area in the East.

These data together suggest a close relationship between the following taxa:

1. Cladonia conistea and $\mathrm{Cl}$. conista; 2. Cladonia pyxidata and Cl. chlorophaea; 3. Cladonia cryptochlorophaea, $\mathrm{Cl}$. merochlorophaea var. merochlorophaea and var. novochlorophaea. The taxa of each of these groups may better be united into single species. The chemical variants within them could be interpreted as chemical strains of lower than specific rank. To confirm this conclusion, it is needed to check the existence outside the Netherlands of correlations between morphological, chemical and ecological characters.

These conclusions largely agree with those drawn for Central Europe by LEUCKERT et al. (1971), who found no distinction between Cladonia pyxidata and $\mathrm{Cl}$. chlorophaea, and no morphological differences between Cladonia cryptochlorophaea, $\mathrm{Cl}$. merochlorophaea, and the novochlorophaeic acid strain.

\section{ACKNOWLEDGEMENTS}

Thanks are due to the Rijksherbarium, Leiden, for loan of material and working facilities, to Dr. J. J. Barkman and Prof. J. L. van Soest for loan of material, to Dr. P. A. Florschütz (Utrecht), Dr. R. A. Maas Geesteranus (Leiden), Drs. E. Hennipman (Leiden), and Drs. R. Pos (Utrecht) for their many valuable advices, to Mr. E. Vijsma (Leiden) for his excellent drawings, and to Dr. K. U. Kramer and Drs. S. R. Gradstein (Utrecht) for their help in preparing this paper.

\section{REFERENCES}

AнтI, T. (1966): Correlation of the chemical and morphological characters in Cladonia chlorophaea and allied lichens. Ann. Bot. Fenn. 3: 380-390.

Asahina, J. (1940): Chemismus der Cladonien unter besonderer Berücksichtigung der japanischen Arten. 1. Cladonia chlorophaea und verwandte Arten. Journ. Japan. Bot. 16: 709-727.

- (1941): Chemismus der Cladonien unter besonderer Berücksichtigung der japanischen Arten. Nachtrag zu Cladonia chlorophaea und verwandte Arten. Journ. Japan. Bot. 17: $431-437$.

Culberson, Ch. F. \& H. Kristinsson (1969): Studies on the Cladonia chlorophaea group: A new species, a new metadepside and the identity of "novochlorophaeic acid". The Bryologist 72: $431-443$.

DAHL, E. (1950): Studies in the macrolichen flora of South West Greenland. Medd. Grönland 150, 2: 1-176.

Hennipman, E. (1969): De Nederlandse Cladonia's (Lichenes). Wetenschappelijke mededelingen $K . N . N . V .79$.

Kristinsson, H. (1971): Morphological and chemical correlations in the Cladonia chlorophaea complex. The Bryologist 74: 13-17.

Leuckert, C. \& J. Poelt (1970): Cladonia conistea in Mitteleuropa. Herzogia 1: 441-445.

-, H. G. Ziegler \& J. Poelt [1972 ("1971")]: Zur Kenntnis der Cladonia chlorophaeaGruppe und ihrer Problematik in Mitteleuropa. Nova Hedwigia 22, 1-2: 503-534.

MaAs Geesteranus, R. A. (1954): Notes on Dutch Lichens. Blumea 7: 570-592.

SANDSTEDE, H. (1931): Die Gattung Cladonia. RABENHORST's Kryptogamenflora 9. Abt. 4, T. 2.

- (1938): Ergänzungen zu Wainio's Monographia Cladoniarum Universalis. Fedde Repertorium, Beihefte Bd. 103.

Shibata, S. \& H.-C. Chinang (1965): The structures of cryptochlorophaeic acid and merochlorophaeic acid. Phytochemistry 4: 133-139.

Thомson, J. W. [1968 ("1967")]: The lichen genus Cladonia in North America. Univ. of Toronto Press. 


\section{EXPLICATION OF THE ABBREVIATIONS}

The abbreviations employed in describing the chemistry are the usual ones in the lichenological literature. They include the following colour reactions:

P: adding a droplet of c. $10 \%$ paraphenylenediamine solution in ethanol. The wetted spot may turn yellow, orange or red. Instead of this highly instable solution (to be replaced after 5 hours) the 'Steiner's solution is used: $1 \%$ paraphenylenediamine and $10 \%$ sodium hyposulfite in distilled water with a trace of a detergent.

$\mathrm{K}$ : adding a droplet of ca $10 \% \mathrm{KOH}$ solution in distilled water. The wetted spot may turn yellow, orange, rosy, red or otherwise within a few minutes.

C: adding a droplet of saturated $\mathrm{CaClO}$ solution in distilled water. This may cause a yellow, rosy, red, green colour. Instead of this pure solution a more stable commercial bleach may be employed (see p. 491).

$\mathrm{KC}$ : adding a droplet of the above-mentioned $\mathrm{KOH}$ solution, followed within a minute by a droplet of the $\mathrm{CaClO}$ solution. This may cause yellow, rosy, green, etc. colours.

In the microcrystal tests the following abbreviations are used:

GAW: a drop of glycerine-ethanol-distilled water mixture $(1: 1: 1)$ is added to the dried lichen extract. After some gentle heating (until boiling) the extracted products may recrystallize and produce much better developped crystals.

GAoT: a drop of glycerine-ethanol-orthotoluidine mixture $(2: 2: 1)$ is added to the dried lichen extract. After gentle heating (until boiling) a reaction between the orthotoluidine and some extracted lichen product may give rise to a substance with characteristic crystals.

The lichen extracts are prepared on an object slide, and for recrystallizing a cover slide is put on the mixture.

For more extensive descriptions of these methods see Thomson (1968).

Legend of figures

Fig. a-c: Cladonia pyxidata. a: Buse s.n. (L, 910.152 157); $b$ : Splitgerber in H.L.B. s.n. (L, 910.153 2429); $c$ : Kers \& Kleef $218(\mathrm{U})$.

Fig. d-e: Cladonia chlorophaea. d: Buse s.n. (L, 910.152 158); e: Sipman 4832 f.

Fig. f-g: Cladonia cryptochlorophaea. $f$ : Groot \& van Soest 1031; $g$ : Groot \& van Soest 2081. Fig. h: Cladonia merochlorophaea var. merochlorophaea. de Smidt record 87, d.d. 17.VII. 1959 (U).

Fig. i: Cladonia merochlorophaea var. novochlorophaea. de Smidt record 31, d.d. 30.VI.1959 (U).

Fig. j-k: Cladonia conistea. j: Groot \& van Soest 1505; $k$ : Sipman 4203. 

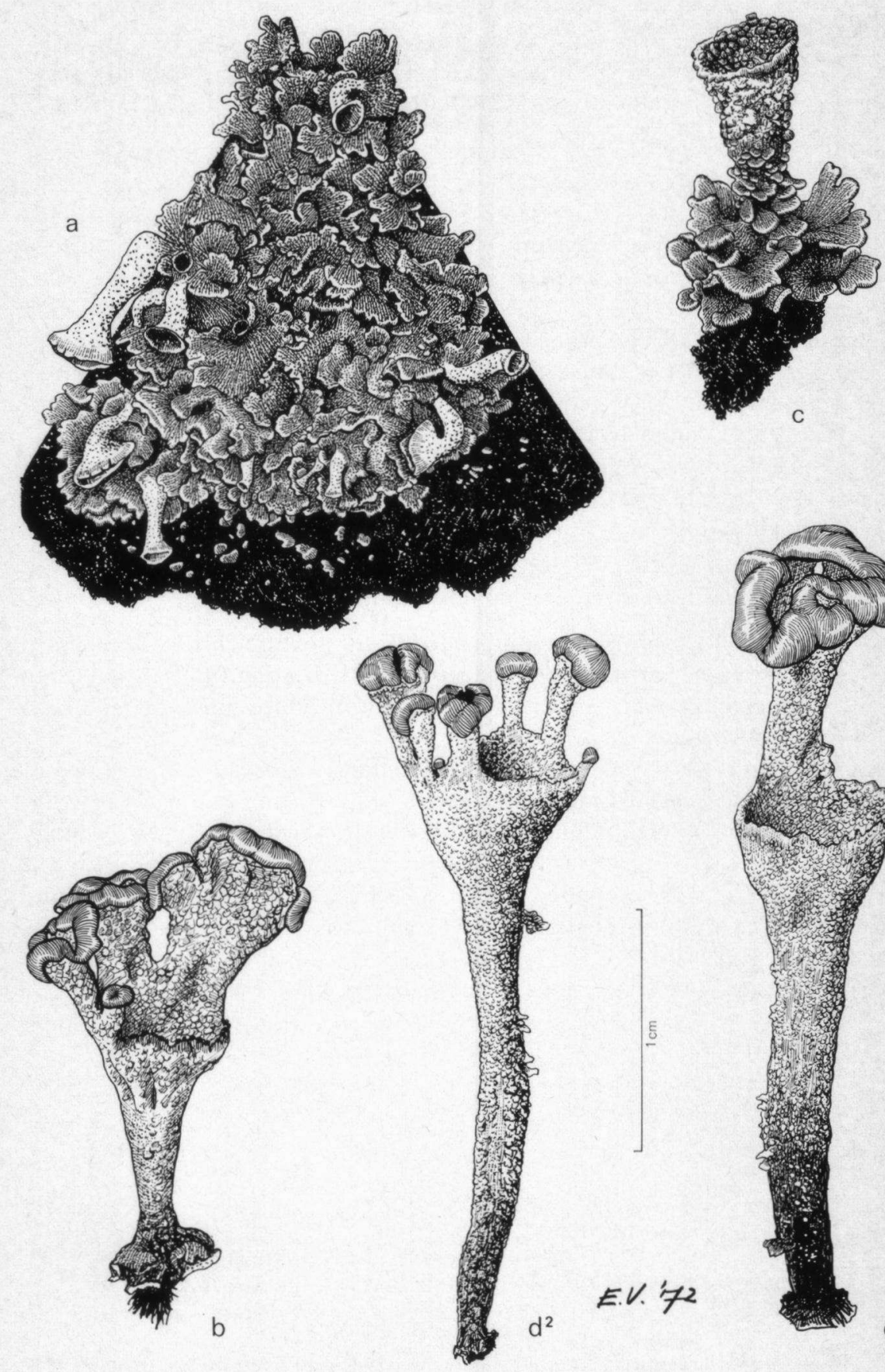
H. J. M. SIPMAN

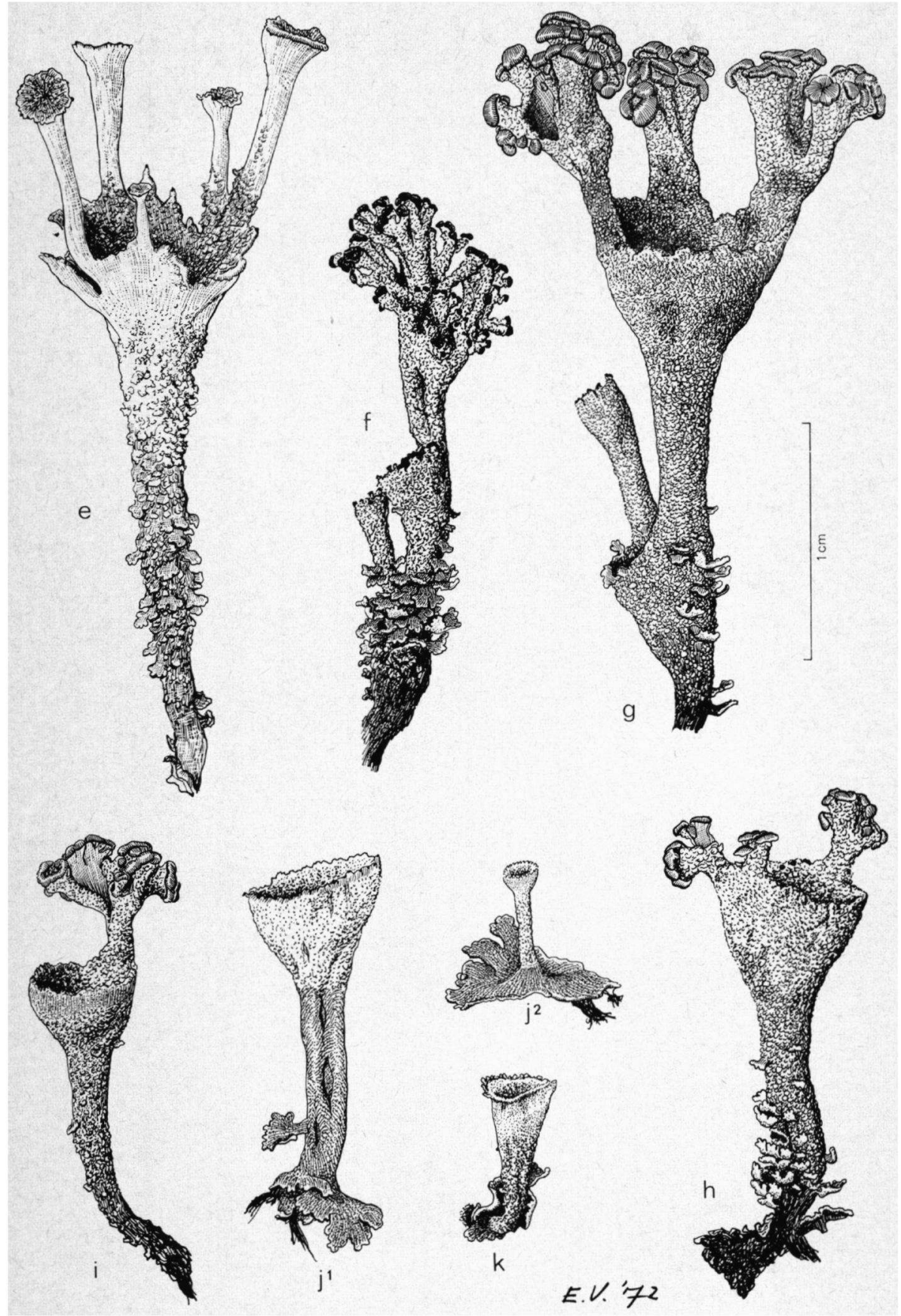

